\title{
The Development of Geopolymer Concrete Mix and Portable Steam Curing Technique
}

\author{
Normarliana Zulkiflee ${ }^{1^{*}}$ and Ahmad Zurisman Mohd $\mathrm{Ali}^{2^{*}}$ \\ ${ }^{1}$ Faculty of Civil and Environmental Engineering, Universiti Hussein Onn Malaysia, 86400, Parit \\ Raja, Batu Pahat, Johor, Malaysia \\ ${ }^{2}$ Jamilus Research Centre, Faculty of Civil and Environmental Engineering, Universiti Tun Hussein \\ Onn Malaysia, 86400 Parit Raja, Batu Pahat, Johor, Malaysia.
}

\begin{abstract}
Geopolymers concrete is environmental-friendly constructions material utilizing waste as the main ingredient in a concrete binder. Various properties of heat-cured geopolymer concrete have shown its suitability for applications such as precast concrete structure. However, the heat-cured method for geopolymers such as steamer generator and a dry-air oven is limited due to the curing system is not mobilized and it is an industrial form. Thus, these types of curing system is not suitable for cast in situ applications. Based on the study carried out, new finding will be proposed to determine the effectiveness of portable steam curing as the new alternative curing technique for geopolymer concrete. Engineering properties of Class $\mathrm{F}$ fly ash based geopolymer concrete after curing with portable steam curing method are study and the corresponding results will be compared with the oven curing method. At the end of the research, the portable steam curing method can offer the effectiveness of geopolymer concrete for cast-in-situ alternatives. Besides, the maximum compressive strength of geopolymer concrete with a portable steam curing can be achieved within 24 hours at $80^{\circ} \mathrm{C}$.
\end{abstract}

\section{Introduction}

This paper presented the effectiveness of portable steam curing technique to heat-cured geopolymer concrete. The new breed of concrete binder is considered as the binder of the future due to less $\mathrm{CO}_{2}$ emission (geo-polymer is the cement-less concrete binder). However, studies of fly ash in Malaysia are still limited. Properties and suitability of fly ash in Malaysia for geopolymer concrete development are not extensively published. Other hands, the government approaches towards Industrialised Building System (IBS) through encouragement and incentive makes geopolymer concrete a perfect fit for the development of the more sustainable nation. This is due to the geopolymer concrete requires 24 hours to achieve its design strength and ready to be used. Hardened of geopolymer concrete are in temperature ranging from $60{ }^{\circ} \mathrm{C}$ to $90{ }^{\circ} \mathrm{C}$ by heat-cured [1]. Steam curing at significant temperature heat $\left(80{ }^{\circ} \mathrm{C}\right)$ for a period of 4 hours can produce an adequate amount of

\footnotetext{
*Corresponding author: normarlianazul@gmail.com
} 
strength for geopolymer concrete [2]. Steam curing technique can produce higher early-age compressive strength and had long-term negative effects on concrete [3].

\section{Materials and experiment}

\subsection{Fly ashes}

Fly ash used in this research is in class F fly ash (ASTM C618) [4] from Mukah coal power plant, Sarawak. The fly ashes are baked in the oven for 24 hours to remove moisture and lump between fly ash particles. The baked fly ashes will be kept in an airtight container to avoid absorbing surrounding moisture. Table 1 shows the chemical composition of the ash by XRF test.

Table 1. The chemical composition of fly ash (\% by mass)

\begin{tabular}{|l|l|l|l|l|l|l|l|l|l|l|}
\hline $\mathrm{SiO}_{2}$ & $\mathrm{Al}_{2} \mathrm{O}_{3}$ & $\mathrm{C}$ & $\mathrm{Fe}_{2} \mathrm{O}_{3}$ & $\mathrm{KO}_{2}$ & $\mathrm{CaO}$ & $\mathrm{MgO}$ & $\mathrm{TiO}_{2}$ & $\mathrm{BaO}$ & $\mathrm{Na}_{2} \mathrm{O}$ & $\mathrm{SO}_{3}$ \\
\hline 47.50 & 25.18 & 0.10 & 12.34 & 3.10 & 5.60 & 2.69 & 0.98 & 0.22 & 0.15 & 1.03 \\
\hline
\end{tabular}

\subsection{Alkaline activator}

8 molar solution of $\mathrm{NaOH}$ was obtained by diluted the $\mathrm{NaOH}$ flakes with distilled water. The ratio of alkali solution $\left(\mathrm{Na}_{2} \mathrm{SiO}_{3}: \mathrm{NaOH}\right)$ for all mixtures was constant at 2.5. Both mixtures are combined together to form alkaline activator for geopolymer concrete. The alkaline activator needs to be prepared a day before use in concrete casting. Alkaline activator plays a vital role in geopolymer concrete by dissolving the reactive of $\mathrm{Si}$ and $\mathrm{Al}$ materials in fly ash and enhances the polymerization reaction.

\subsection{Mix design preparation and curing of geopolymer concrete}

Fresh geopolymer concrete are prepared which consisted of fly ash, sodium hydroxide $(\mathrm{NaOH})$, sodium silicate $\left(\mathrm{Na}_{2} \mathrm{SiO}_{3}\right)$, coarse aggregate, and fine aggregate. $100 \mathrm{~mm} \times 100 \mathrm{~mm}$ $\mathrm{x} 100 \mathrm{~mm}$ cube mold was used to cast the fresh geopolymer concrete mix. Table 2 shows the mix design of fresh geopolymer concrete. The specimens were cured with a portable steamer in a recycle canvas blanket (Fig. 1 (a)). The portable steamer was set to $80^{\circ} \mathrm{C}$ for 24 hours. Specimens by using oven curing (Fig. 1 (b)), were prepared at $80^{\circ} \mathrm{C}$ for 24 hours for comparison purposed. After a day of curing, both specimens were rested for at least 2 hours before demoulding.

Table 2. Mix Design of fresh geopolymer concrete composition $\left(\mathrm{kg} / \mathrm{m}^{3}\right)$

\begin{tabular}{|l|l|l|l|l|l|l|l|l|}
\hline & $\begin{array}{l}\text { Fly } \\
\text { ash }\end{array}$ & $\mathrm{NaOH}$ & $\mathrm{Na}_{2} \mathrm{Si}_{3}$ & Water & $\begin{array}{l}\text { Course } \\
\text { Aggregates }\end{array}$ & $\begin{array}{l}\text { Fine } \\
\text { Aggregates }\end{array}$ & Temp. & $\begin{array}{l}\text { Curing } \\
\text { method }\end{array}$ \\
\hline GPC1 & 3.2 & 0.12 & 0.21 & 1.6 & 14.02 & 1.58 & $80^{\circ} \mathrm{C}$ & $\begin{array}{l}\text { Portable } \\
\text { steamer }\end{array}$ \\
\hline GPC2 & 3.2 & 0.12 & 0.21 & 1.6 & 14.02 & 1.58 & $80^{\circ} \mathrm{C}$ & Oven \\
\hline
\end{tabular}




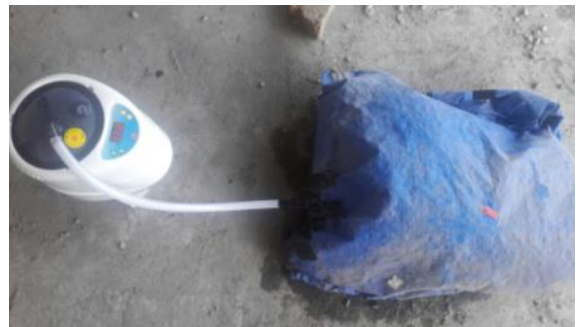

(a)

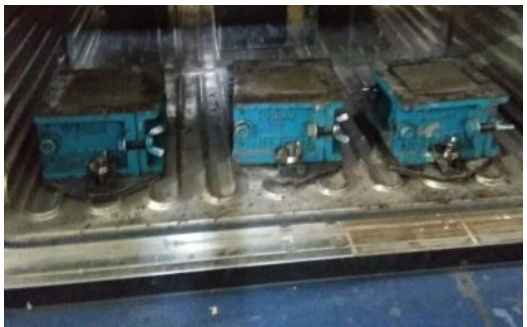

(b)

Fig. 1. (a) Portable steam curing, (b) Oven curing

\section{Results}

\subsection{Compressive strength}

In this experimental works, the geopolymer concrete cubes are tested under compressive strength testing (BS EN 12390-3:2009) [5]. The compressive strength of the geopolymer concrete needs to achieve the nominal compressive strength of $35 \mathrm{MPa}$. The average compressive strength test result is presented in Table 3. Specimen GPC 2 obtained the highest strength with $80 \mathrm{MPa}$ for 24 hours of curing temperature at $80^{\circ} \mathrm{C}$. Specimen curing with portable steam curing gain maturity with a compressive strength of $57 \mathrm{MPa}$ at the same temperature and curing time as oven curing. This accelerated compressive strength is due to the polymerization reaction in geopolymer concrete at elevated curing temperature [6]. From recent studies, the highest of compressive strength is gained with the $60-80^{\circ} \mathrm{C}$ temperature range for 6-12 hours of curing time [7]. Fig. 2 showed the compressive strength of each specimen for both curing techniques.

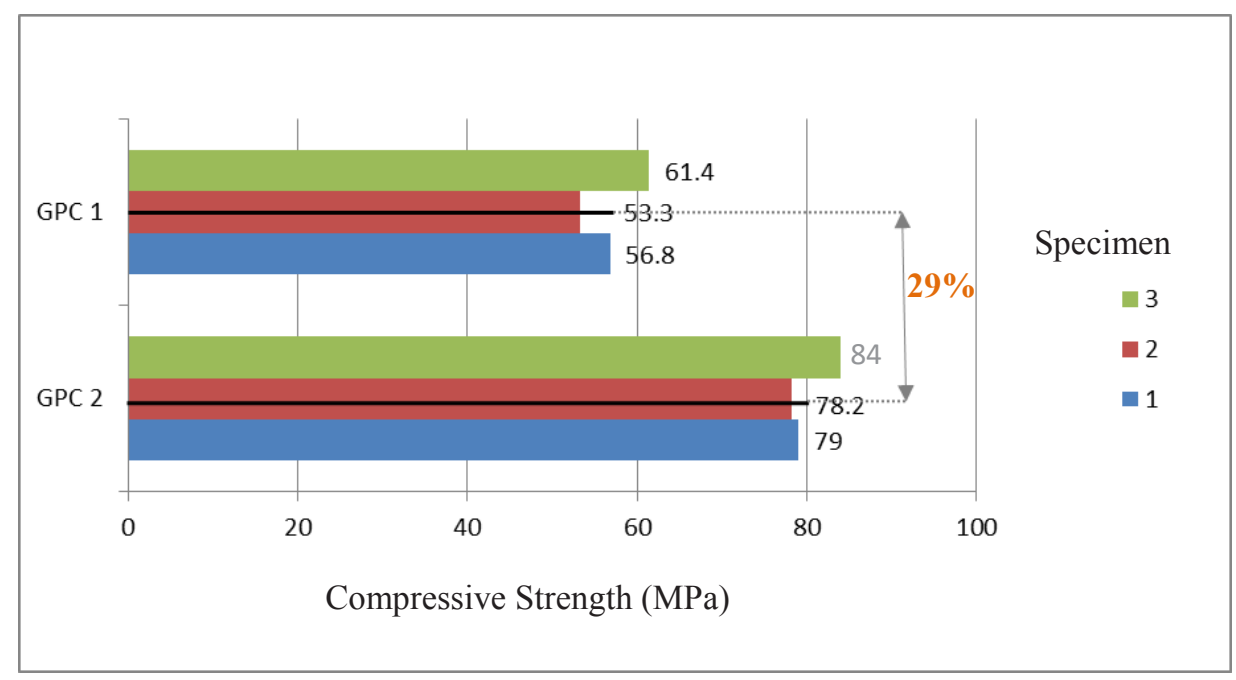

Fig. 2. Compressive strength (MPa) each of the specimen for both curing technique. 
Table 3. Average value compressive strength of geopolymer concrete (MPa)

\begin{tabular}{|c|c|}
\hline Specimen & $\begin{array}{c}\text { Compressive strength } \\
\text { (MPa) }\end{array}$ \\
\hline GPC 1 & 57.2 \\
\hline GPC 2 & 80.4 \\
\hline
\end{tabular}

\section{Conclusion}

Both ovens and steam curing technique are show improvement in GPC compressive strength. However, this technique uses machines in the form of lab / industrial scale and is not suitable for cast-in-situ applications. Due to this research gap, an initiative is proposed and reviewed to overcome this problem by using a portable steam curing technique to heatcured the geo-polymer concrete. From the experimental results, GPC1 by using portable steam curing are achieving $57 \mathrm{MPa}$ while GPC2 oven curing has the highest compressive strength of $80 \mathrm{MPa}$. These prove that the portable steam curing technique is effective for geopolymer concrete curing and suitable for a cast-in-situ application. The geopolimerization process and elevated curing temperature also play important role in the enhancement of compressive strength in geopolymer concrete.

The authors want to thank Universiti Tun Hussein Onn Malaysia (UTHM) for providing laboratory facilities and Research Management Centre (RMC UTHM) for providing research fund under the Postgraduate Research Grant (GPPS) project no. U946 for this study.

\section{References}

1. ASTM C618. Standard Specification for Coal Fly Ash and Raw or Calcined Natural Pozzolan for Use in concrete, ASTM. West Conshohocken: ASTM. (2015).

2. BS EN 12390-3. Testing hardened concrete. The compressive strength of test specimens (2009).

3. Corominas, A. G., \& Etxeberria, M.. Steam Curing Effect on the Properties of Fly Ash High Performance. 4th International Conference on Sustainable Construction Materials and Technologies. Last Vegas: Department of Construction Engineering, Polytechnic University of Catalonia, Jordi Girona (2016).

4. J. Davidovits, Geopolymer: Chemistry \& Applications (Institut Geopolymere, France, 2008).

5. P. Duxson, A. Fernandez-Jimenez, J.L. Provis, G. Lukey, A. Palomo, J.S.J. van

Deventer. Geopolymer technology: The current state of the art. Journal of Materials Science, 42(9): 2917-2933 (2007).

6. Siddiqui, K.S. Strength, and durability of low-calcium fly ash based geopolymer concrete. M.Sc. Thesis, The University of Western Australia, Perth, Australia (2007).

7. Škvára, F., Jílek, T. and Kopecký, L. 2005. Geopolymer materials based on fly ash. Ceramics - Silikáty, vol. 49 (3), pp. 195-204 (2005). 